\title{
Overexpression of Glial Cell Line-Derived Neurotrophic Factor Using a Lentiviral Vector Induces Time- and Dose- Dependent Downregulation of Tyrosine Hydroxylase in the Intact Nigrostriatal Dopamine System
}

\author{
Biljana Georgievska, Deniz Kirik, and Anders Björklund \\ Department of Physiological Sciences, Division of Neurobiology, Wallenberg Neuroscience Center, Lund University, 22184 Lund, Sweden
}

\begin{abstract}
The effects of continuous glial cell line-derived neurotrophic factor (GDNF) overexpression in the intact nigrostriatal dopamine (DA) system was studied using recombinant lentiviral (rLV) vector delivery of GDNF to the striatum or substantia nigra (SN) in the rat. Intrastriatal delivery of rLV-GDNF resulted in significant overexpression of GDNF in the striatum $(2-4 \mathrm{ng} / \mathrm{mg}$ tissue) and anterograde transport of GDNF protein to the SN. Striatal rLV-GDNF delivery initially induced an increase in DA turnover (1- 6 weeks), accompanied by significant contralateral turning in response to amphetamine, suggesting an enhancement of the DA system on the injected side. Starting 6 weeks after continuous GDNF delivery, we observed a selective downregulation of tyrosine hydroxylase $(\mathrm{TH})$ protein $(\approx 70 \%)$ that was maintained until the end of the experiment ( 24 weeks). A similar effect was observed when rLV-GDNF was injected into the SN. The magnitude of TH downregulation was related to the level of GDNF expression and was most pronounced in animals in which the striatal GDNF level exceeded $0.7 \mathrm{ng} / \mathrm{mg}$ tissue. The decreased TH protein levels were associated with similar reductions in the in vitro TH enzyme activity $(\approx 70 \%)$; however, in vivo L-3,4-dihydroxyphenylalanine production rate and DA tissue levels were maintained at normal levels. The results indicate that downregulation of TH protein reflects a compensatory effect in response to continuous GDNF stimulation of the DA neurons mediated by a combination of overactivity at the DA synapse and a direct GDNF-induced action on TH gene expression. This compensatory mechanism is proposed to maintain long-term DA neuron function within the normal range.
\end{abstract}

Key words: dopamine; Parkinson; downregulation; gene therapy; glial cell line-derived neurotrophic factor; intact; overexpression; Parkinson's disease; tyrosine hydroxylase

\section{Introduction}

Glial cell line-derived neurotrophic factor (GDNF) is a potent survival factor for injured nigrostriatal dopamine (DA) neurons and is currently being evaluated as a potential treatment for Parkinson's disease (PD) (Gill et al., 2003). Previous studies using intracerebral injections of recombinant GDNF protein in animal models of PD have shown that GDNF can efficiently protect injured DA neurons (Beck et al., 1995; Sauer et al., 1995; Tomac et al., 1995; Kearns et al., 1997), promote regenerative sprouting from axotomized DA axons (Kirik et al., 2000a; Rosenblad et al., 2000a), and stimulate DA turnover and release in rescued neurons (Björklund et al., 1997; Gash et al., 1998). In intact animals, injections of GDNF protein into either substantia nigra (SN) or

Received Dec. 2, 2003; revised May 27, 2004; accepted May 27, 2004.

This work was supported by Swedish Research Council Grants K2000-99-XG-13285-02B and 04X-3874, and the lentiviral vectors were produced by the Vector Core of the Swedish Gene Therapy Program (Lund, Sweden). We thank Kerstin Fogelström, Ulla Jarl, Anneli Josefsson, and Bengt Mattsson for excellent technical support; Pia Weikop (Neurosearch, Ballerup, Denmark) for the HPLC analyses; Dr. Lachlan Thompson for helpful assistance in capturing confocal images; and Dr. Carl Rosenblad for helpful discussions in the preparation of this manuscript.

Correspondence should be addressed to Biljana Georgievska, Division of Neurobiology, Biomedical Center A11, 22184 Lund, Sweden. E-mail: Biljana.Georgievska@mphy.lu.se.

DOI:10.1523/JNEUROSCI.1122-04.2004

Copyright $\odot 2004$ Society for Neuroscience $\quad$ 0270-6474/04/246437-09\$15.00/0 striatum have been shown to enhance DA neuron function by increasing DA turnover and release, accompanied by increases in both spontaneous and amphetamine-induced locomotor activity (Hudson et al., 1995; Hebert et al., 1996; Martin et al., 1996a; Hebert and Gerhardt, 1997; Horger et al., 1998; Kobayashi et al., 1998). In addition, GDNF can increase the neuronal excitability (Yang et al., 2001; Wang et al., 2003) and the quantal size of terminal DA release from DA neurons in culture (Pothos et al., 1998).

Long-term expression of GDNF after direct in vivo delivery of the GDNF gene to the nigrostriatal DA system has been achieved using recombinant adenovirus, recombinant adeno-associated virus (rAAV), and recombinant lentivirus ( $\mathrm{rLV}$ ) vectors (Björklund et al., 2000). The GDNF levels obtained from these vector systems have been as efficient as protein injections in protecting nigral DA neurons in animal models of PD (Bilang-Bleuel et al., 1997; Choi-Lundberg et al., 1997; Mandel et al., 1997; Kirik et al., 2000b; Kordower et al., 2000; Rosenblad et al., 2000b; Georgievska et al., 2002b). In a previous study, we used an rLV vector to deliver GDNF to the striatum before an intrastriatal 6-hydroxydopamine (6-OHDA) lesion (Georgievska et al., 2002a). Striatal overexpression of GDNF at a high level (2 ng/mg tissue) over a prolonged period ( 9 months) efficiently protected the nigrostriatal DA cell bodies as well as their projections to the 
striatum; however, the animals remained functionally impaired. Unexpectedly, we also observed a downregulation of tyrosine hydroxylase $(\mathrm{TH})$ in the preserved striatal DA terminals in the GDNF-treated animals. A similar downregulation of TH protein has been reported in intact animals after 13 months of continuous rLV-mediated GDNF overexpression in the striatum (Rosenblad et al., 2003). The purpose of the present study was to investigate the effect of long-term continuous GDNF delivery on the TH enzyme and on normal DA function in the intact nigrostriatal DA system. Initially, the GDNF-treated animals displayed an increased DA turnover and potentiation of amphetamine-induced rotation, suggesting a stimulatory effect on DA transmission. By 6 weeks, this effect had subsided and had been replaced by a substantial and selective downregulation of the TH protein in the GDNF-treated striatum. However, the tissue DA levels remained normal, suggesting that downregulation of $\mathrm{TH}$ in the intact nigrostriatal DA system is not detrimental to normal DA function.

\section{Materials and Methods}

Subjects. A total of 185 adult female Sprague Dawley rats (B\&K Universal, Stockholm, Sweden) were used. The animals were housed two to three per cage under a $12 \mathrm{hr}$ light/dark cycle with ad libitum access to rat chow and water. Housing and treatment of the animals was conducted according to the rules set by the Lund University Ethical Committee for Use of Laboratory Animals.

Experimental design. Three experiments were designed to determine the time-, dose-, and site-dependent effects, respectively, of GDNF overexpression on the intact nigrostriatal DA system. In experiment $1, \mathrm{rLV}$ vectors encoding either GDNF $(n=60)$ or the marker gene green fluorescent protein (GFP; $n=60$ ) were injected in the striatum. The dose of the $\mathrm{rLV}$-GDNF vector injected was determined to be $1 \times 10^{5}$ transducing units (TU) in total. During the time course of the experiment, a majority of the animals $(n=90)$ were tested repeatedly on amphetamine-induced rotation, and subgroups of animals were killed at 1 week $(n=30), 3$ weeks $(n=30), 6$ weeks $(n=30), 12$ weeks $(n=20)$, and 24 weeks $(n=$ $10)$ after the vector injection. The brains were processed for either histo$\operatorname{logical}(n=10$ at $1,3,6$, and 12 weeks) or biochemical ( $n=20$ at 1,3 , and 6 weeks; $n=10$ at 12 and 24 weeks) analyses. In experiment 2, the rLV-GDNF vector from experiment 1 was diluted 3-, 9-, or 27-fold, and 35 animals received striatal injections of the different doses of rLVGDNF (ranging from $4 \times 10^{3}$ to $1 \times 10^{5} \mathrm{TU}$ ). The control rLV-GFP vector was injected at $3 \times 10^{5} \mathrm{TU}$ in 10 animals. The animals were killed 6 weeks after injection, and the brains were processed for either histological $(n=16)$ or biochemical $(n=29)$ analyses. In experiment $3,1 \times 10^{5}$ $\mathrm{TU}$ of the rLV vectors were injected into the SN in 20 animals $(n=10$ per vector group). The animals were killed 6 weeks after injection, and the brains were processed for histological $(n=10)$ or biochemical $(n=10)$ analyses.

Recombinant lentiviral vector production. The transfer construct encoding enhanced GFP (catalog number 632385; Clontech, Palo Alto, CA) or human GDNF (rLV.CMV.GFP.W or rLV.CMV.GDNF.W), the packaging construct ( $\mathrm{pCMV} \Delta \mathrm{R} 8.91$ ), and the envelope plasmid encoding the vesicular stomatitis virus G-protein (pMD.G) were cotransfected into $293 \mathrm{~T}$ cells, and virions released into the media were collected at 48 and 72 hr after transfection. To concentrate the viral particles, the media were ultracentrifuged for two rounds at 26,000 rpm ( $1.5 \mathrm{hr} /$ round), and the final pellet was dissolved in DMEM, $10 \%$ FBS, and $1 \%$ glutamine. The number of TU of the concentrated rLV-GFP vector stock was determined on $293 \mathrm{~T}$ cells. The cells were plated at a density of $1 \times 10^{5}$ cells per well in six-well tissue culture dishes. Serial dilutions of the vector stock were added, and the number of GFP-expressing cells was analyzed $48 \mathrm{hr}$ later. An RNA slot blot technique (von Schwedler et al., 1993) was subsequently used to determine viral particle titer for both the GFP and GDNF vector stocks. The number of TU of the GDNF-expressing vector was estimated on the basis of the ratio between viral particle titer and TU as determined for the rLV-GFP vector. The final titer of the rLV-GFP vector stocks was $2.9-4.6 \times 10^{8} \mathrm{TU} / \mathrm{ml}$, and the titer of the $\mathrm{rLV}-\mathrm{GDNF}$ vector stocks was estimated at $1.8-2.3 \times 10^{8} \mathrm{TU} / \mathrm{ml}$. For experiments 1 and 3 , both vector stocks were diluted fivefold in saline before injection. In experiment 2 , the fivefold diluted rLV-GDNF vector was further diluted 3-, 9-, and 27-fold before injection.

$r L V$ injections. The rLV injections were made under halothane anesthesia using a $10 \mu \mathrm{l}$ Hamilton (Reno, NV) syringe fitted with a glass micropipette (outer diameter, $\approx 60-80 \mu \mathrm{m}$ ). All injections were made stereotaxically using a Kopf stereotaxic frame (David Kopf Instruments, Tujunga, CA).

Striatal injections. A total of $3 \mu \mathrm{l}$ of rLV-GDNF $(n=95)$ or rLV-GFP $(n=70)$ was injected into the right striatum. The injections were made as two $0.5 \mu \mathrm{l}$ deposits along each of the three needle tracts at the following coordinates: (1) anteroposterior $(\mathrm{AP})=+1.4$, mediolateral $(\mathrm{ML})=$ -2.6 , dorsoventral $(\mathrm{DV})=-5.0,-4.0$; (2) $\mathrm{AP}=+0.4, \mathrm{ML}=-3.4$, $\mathrm{DV}=-5.0,-4.0$; and (3) $\mathrm{AP}=-0.8, \mathrm{ML}=-4.4, \mathrm{DV}=-5.0,-4.0$, relative to bregma; the tooth bar was set at 0.0 . The injection rate was 1 $\mu \mathrm{l} / \mathrm{min}$ and the glass pipette was left in place for an additional $3 \mathrm{~min}$ before withdrawal.

Nigral injections. A total of $2 \mu \mathrm{l}$ of rLV-GDNF $(n=10)$ or rLV-GFP $(n=10)$ was injected above the right $\mathrm{SN}$ at the following coordinates: $\mathrm{AP}=-5.3, \mathrm{ML}=-2.0, \mathrm{DV}=-7.2$; the tooth bar was set to -2.3 . The injection rate was $0.5 \mu \mathrm{l} / \mathrm{min}$, and the glass pipette was left in place for an additional $5 \mathrm{~min}$ before withdrawal.

Amphetamine-induced rotation. The animals were injected with amphetamine ( $2.5 \mathrm{mg} / \mathrm{kg}$, i.p.; Apoteksbolaget, Lund, Sweden), and rotational behavior was assessed in automated rotometer bowls for $90 \mathrm{~min}$. Rotational asymmetry scores are expressed as net $360^{\circ}$ turns per minute.

Biochemical analyses. Subgroups of animals from experiment 1 (rLVGDNF injected, $n=25$; rLV-GFP injected, $n=25)$, experiment 2 ( $\mathrm{rLV}$ GDNF injected, $n=23$; rLV-GFP injected, $n=6$ ), and experiment 3 ( $\mathrm{rLV}$-GDNF injected, $n=5$; rLV-GFP injected, $n=5$ ) were killed for biochemical analyses of GDNF protein levels (using ELISA), TH protein levels (using Western blot analysis), TH enzyme activity, and levels of L-3,4-dihydroxyphenylalanine (DOPA) and DA. The animals that were killed for analysis of DOPA levels received an injection of the L-aromatic acid decarboxylase (AADC) inhibitor NSD-1015 (3-hydroxybenzylhydrazine dihydrochloride; $100 \mathrm{mg} / \mathrm{kg}$, i.p.; Sigma, St. Louis, MO) 30 min before decapitation. Inhibition of DOPA decarboxylase results in an accumulation of DOPA, thus providing an in vivo measure of the DOPA production rate without any decrease in the tissue DA levels during the 30 min period before decapitation (Schmidt et al., 1982). In addition, animals from experiment 1 were killed for HPLC analyses of DA, DOPAC, and homovanillic acid (HVA) tissue levels at 1, 3, and 6 weeks (rLV-GDNF injected, $n=15$; rLV-GFP injected, $n=15$ ) after vector injection. The brains were rapidly removed, and the striatum was dissected bilaterally, dorsal to the anterior commissure and freed from cortex and septum. The dissected striatum was chopped into smaller pieces, mixed, and divided into three parts that were frozen separately. One part was used for GDNF ELISA, a second part was used for TH enzyme activity assay and Western blot analysis, and the third part was used for measurements of DOPA, DA, DOPAC, and HVA. For experiments 2 and 3, the ventrolateral part of the midbrain was cut to include the $\mathrm{SN}$ region for GDNF ELISA. For experiment 1, the midbrain was taken for microscopic analysis.

GDNF determination by ELISA. The frozen tissue samples from the striatum and $\mathrm{SN}$ were sonicated in a homogenization buffer $(50 \mathrm{~mm}$ Tris, pH 7.4, $150 \mathrm{~mm} \mathrm{NaCl}, 1 \%$ Triton X-100, $1.7 \mu \mathrm{g} / \mathrm{ml}$ phenylmethylsulfonyl fluoride, $1.0 \mu \mathrm{g} / \mathrm{ml}$ leupeptin, $10 \mu \mathrm{g} / \mathrm{ml}$ aprotinin, and $1.0 \mu \mathrm{g} / \mathrm{ml} \mathrm{pep-}$ statin) at a tissue concentration of $30 \mathrm{mg} / \mathrm{ml}$ and centrifuged at $20,000 \times$ $g$ for $10 \mathrm{~min}$ at $4^{\circ} \mathrm{C}$. Tissue levels of GDNF were determined on homogenates by ELISA according to the recommendations of the supplier (G3240; Promega, Madison, WI).

TH enzyme activity assay was performed according to Reinhard et al. (1986). In brief, the striatal tissue was sonicated in $10 \mu \mathrm{l} / \mathrm{mg}$ homogenization buffer (20 mм MES, pH 6.1, 0.2\% Triton X-100) and centrifuged at $20,000 \times g$ for $10 \mathrm{~min}$ at $4^{\circ} \mathrm{C}$. The supernatant was collected and divided into two parts; one part was used for the TH enzyme activity assay, and the other part was used for Western blot analysis (see below). A mixture of $\mathrm{L}-\left[3,5-{ }^{3} \mathrm{H}\right]$ tyrosine (Amersham Biosciences, Little 

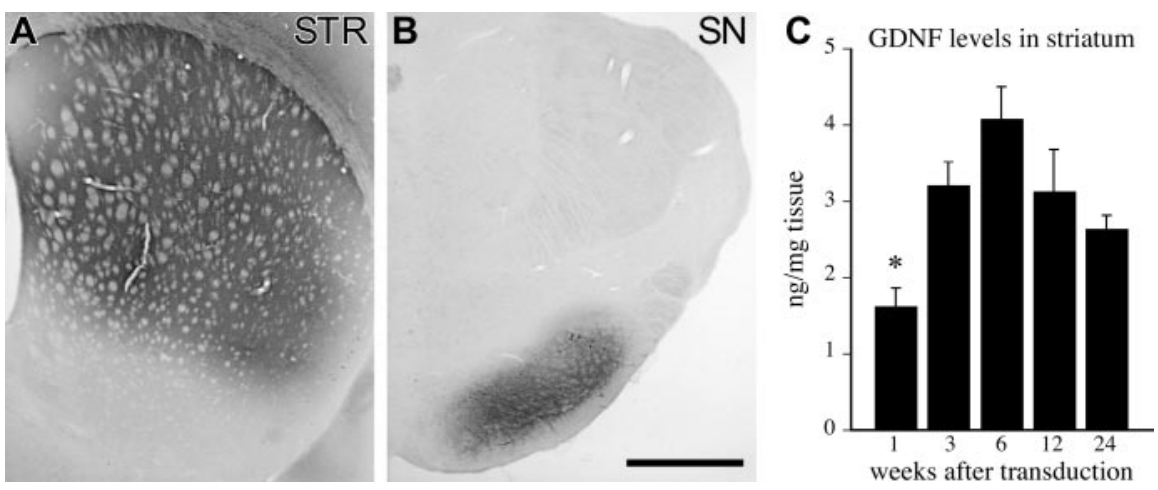

Figure 1. Time course of GDNF expression after intrastriatal injections of rLV-GDNF $\left(1 \times 10^{5} \mathrm{TU}\right) . A, B$, Photomicrographs of sections through striatum $(A)$ and midbrain $(B)$ immunostained for GDNF at 6 weeks after rLV-GDNF injection, illustrating the widespread distribution of GDNF in the striatum and anterograde transport of GDNF protein to the SN pars reticulata region. Scale bar: (in $B) A, B, 1 \mathrm{~mm}$. C, Determination of GDNF tissue levels (nanograms per milligram of tissue) as measured by ELISA in the striatum at different time points after rLV-GDNF injection. GDNF was detected at all time points (1-24 weeks), and the levels were between 1.6 and $4.2 \mathrm{ng} / \mathrm{mg}$ tissue. The level at 1 week after surgery was significantly lower than the level measured at 6 weeks $\left({ }^{*} p<0.01\right)$. Values give means \pm SEM

Chalfont, UK), $500 \mu \mathrm{m}$ L-tyrosine (Sigma), $200 \mathrm{~mm}$ MES, pH 6.1, $84 \mathrm{mg}$ of catalase (Sigma), and $\mathrm{dH}_{2} \mathrm{O}$ was mixed and added together with the cofactor biopterin $(0.6 \mathrm{mg} / \mathrm{ml}$; dissolved in $3 \mathrm{mg} / \mathrm{ml}$ DTT; Sigma/RBI, Natick, MA) to $10 \mu$ l of the supernatant, and the samples were incubated for $20 \mathrm{~min}$ at $37^{\circ} \mathrm{C}$. The reaction was terminated by adding charcoal- $\mathrm{HCl}$, and the samples were then centrifuged at $20,000 \times g$ for $15 \mathrm{~min}$. One hundred microliters of the supernatant were transferred to a scintillation vial, and $5 \mathrm{ml}$ of scintillation liquid (Insta-Gel PLUS; CIAB, Lindingö, Sweden) was added. The number of decays per minute was measured in a liquid scintillation counter (1214 RACKBETA; LKB-Wallac, Gaithersburg, MD).

Western blot analysis. The determination of the protein concentration in the supernatant from the homogenized striatal tissue samples taken for TH enzyme activity assay (see above) was performed using the Bradford method (Bio-Rad, Hercules, CA). The samples were mixed 1:1 with Laemmli buffer (Bio-Rad), supplemented with 5\% mercaptoethanol (Sigma), and then frozen. From each sample, $4 \mu \mathrm{g}$ of protein was boiled for $5 \mathrm{~min}$ before loading on a $4-20 \%$ Tris- $\mathrm{HCl}$ gel (Bio-Rad; running conditions: $150 \mathrm{~V}$ for $\sim 90 \mathrm{~min}$ ). The gel was electroblotted onto a polyvinylidene difluoride membrane (Bio-Rad; transferring conditions: $50 \mathrm{~V}$ for $2 \mathrm{hr}$ ) and probed with a primary antibody against TH (rabbit IgG, 1:1000; Chemicon, Temecula, CA) overnight at room temperature. The next day, the membrane was incubated for $1 \mathrm{hr}$ with an HRP-conjugated anti-rabbit antibody (1:2000; Amersham Biosciences). The protein bands were detected by enhanced chemiluminescence (ECL; Amersham Biosciences) and exposed to Hyperfilm ECL (Amersham Biosciences).

Measurements of DA and its metabolites. DOPA and DA levels were analyzed using a combined radioenzymatic method, as described by Schmidt et al. (1982). In addition, DA, DOPAC, and HVA tissue levels were determined using HPLC (Lotharius et al., 2002).

Histological analyses. Subgroups of animals from experiment 1 (rLVGDNF injected, $n=20$; rLV-GFP injected, $n=20$ ), experiment 2 (rLVGDNF injected, $n=12$; rLV-GFP injected, $n=4)$, and experiment 3 ( $r L V-G D N F$ injected, $n=5$; rLV-GFP injected, $n=5$ ) were killed for histological analyses. The animals were deeply anesthetized with sodium pentobarbital and transcardially perfused with $50 \mathrm{ml}$ of isotonic saline followed by $250 \mathrm{ml}$ of ice-cold $4 \%$ paraformaldehyde in $0.1 \mathrm{M}$ phosphate buffer (PB), pH 7.4. The brains were dissected and postfixed in the same fixative for $2 \mathrm{hr}$ and transferred into $25 \%$ sucrose in $0.1 \mathrm{M} \mathrm{PB}$ before sectioning on a freezing microtome at $40 \mu \mathrm{m}$ thickness and eight series. Immunohistochemistry was performed using antibodies raised against GDNF (goat IgG, 1:2000; R\&D Systems, Minneapolis, MN), TH (mouse IgG, 1:2000; Chemicon), and vesicular monoamine transporter 2 (VMAT-2; rabbit IgG, 1:2000; Chemicon). The sections were quenched for 10 min in $3 \% \mathrm{H}_{2} \mathrm{O}_{2}$ and $10 \%$ methanol in $\mathrm{PB}$, preincubated in $5 \%$ serum and $0.25 \%$ Triton X-100, and incubated overnight at room tempera- ture with the primary antibody. This was followed by incubation with a 1:200 dilution of biotinylated secondary horse anti-goat (BA9500; Vector Laboratories, Burlingame, CA), horse antimouse (BA2001; Vector Laboratories), and goat anti-rabbit (BA1000; Vector Laboratories), respectively. The reaction product was visualized with avidin-biotin-peroxidase complex $(\mathrm{ABC}$ Elite; Vector Laboratories) using $3^{\prime}, 3^{\prime}$ diaminobenzidine as a chromogen. The sections were mounted on chrom-alum-coated glass slides, dehydrated in ascending alcohol solutions, cleared in xylene, and coverslipped with Depex mounting medium.

Double labeling for TH and GFP was performed using antibodies against $\mathrm{TH}$ (see above) and GFP (rabbit IgG, 1:20,000; Abcam, Cambridge, UK) followed by incubation with a biotinylated horse anti-mouse antibody (see above) and cyanine 3-conjugated streptavidin (1:200; Jackson ImmunoResearch, West Grove, PA) for TH and cyanine 2 donkey antirabbit (1:200; Jackson ImmunoResearch) for GFP. The sections were mounted and coverslipped with polyvinyl alcohol-1,4-diazabicyclo[2.2.2] octane.

Morphometric analyses. Quantification of TH protein levels was performed by scanning films of Western blots and measuring the optical density (OD) of the TH bands using the NIH Image 1.62 program. The relative $\mathrm{TH}$ bands were calculated by subtracting the background $\mathrm{OD}$ from the measured OD of the TH bands. TH protein levels in the treated (right) and nontreated (left) striatum from the same animal were determined within the same Western blot, and the results were confirmed by duplicates and expressed as a percentage of contralateral nontreated side.

TH-positive and VMAT-2-positive striatal immunoreactivity was assessed by measuring the OD of the immunostained fibers in the striatum using the NIH Image 1.62 program on a Macintosh 9500 computer connected to a digital ProgRes camera (Kontron Elektronik, Eching, Germany) and a constant illumination table. For each animal, the OD was measured from the entire cross section of the striatum at three rostrocaudal levels corresponding to: $\mathrm{AP}=+1.0, \mathrm{AP}=-0.26$, and $\mathrm{AP}=$ -0.92 , relative to bregma, according to the atlas of Paxinos and Watson (1998). The readings were corrected for nonspecific background by measuring the corpus callosum in each section and expressed as a percentage of control side value.

Statistical analysis. Differences between treatments were assessed using ANOVA and were followed, when significant, by Student-NewmanKeuls post hoc analysis for group comparisons. Significance was accepted at the $95 \%$ probability level.

\section{Results \\ Expression and distribution of GDNF after rLV vector delivery to the striatum}

Injection of $\mathrm{rLV}$-GDNF $\left(1 \times 10^{5} \mathrm{TU}\right)$ into the striatum resulted in a widespread distribution of GDNF protein in the striatum (Fig. 1A) and transport of GDNF to the SN, primarily the pars reticulata (Fig. $1 B$ ). In addition, in animals injected with the rLV-GFP vector, GFP-positive striatonigral fibers were observed in the pars reticulata, whereas no GFP-positive cells could be detected in the SN (data not shown). These observations suggest that GDNF may, at least in part, be transported anterogradely and released from the striatonigral terminals; however, we cannot exclude the possibility for coexistence of a retrograde transport of GDNF. The GDNF protein levels in the striatum were determined for each time point (Fig. 1C), and detectable levels were observed already at 1 week after injection $(1.6 \pm 0.3 \mathrm{ng} / \mathrm{mg}$ tissue). The expression level increased significantly at the later time points (effect of time point, $F_{(4,39)}=4.77 ; p<0.01$ ) ranging 

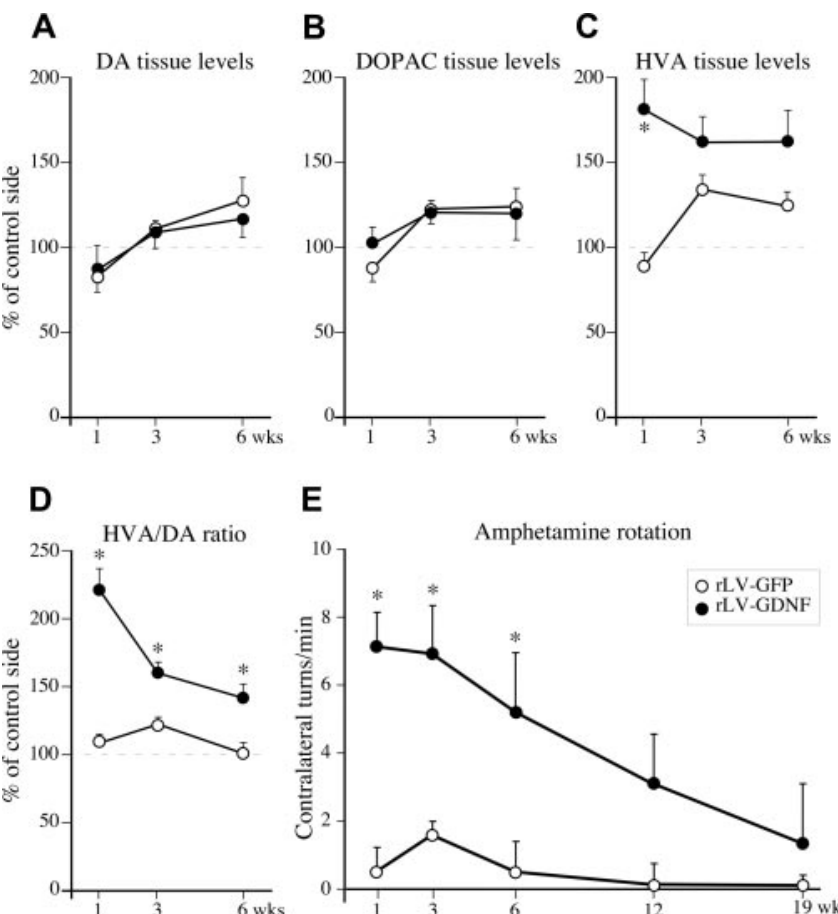

\section{E}

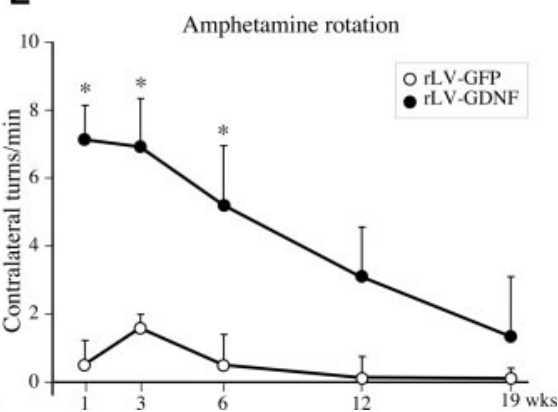

Figure 2. Changes in striatal DA turnover and amphetamine-induced rotation over time $A-C$, Striatal tissue levels of DA $(A)$ and DOPAC $(B)$ were unchanged in the rLV-GDNF-treated animals, whereas the HVA tissue levels ( $C$ ) were significantly increased at 1 week after rLV injection. $D$, The HVA/DA ratio (reflecting the DA turnover and release) was significantly ( $p<$ 0.0001 ) increased in the rLV-GDNF group at all time points; however, the DA turnover decreased over time. $E$, Injection of amphetamine induced a significant $(p<0.01)$ contralateral turning in the GDNF-treated animals at 1,3 , and 6 weeks $(\approx 5-7$ turns $/ \mathrm{min}$ ). At the later time points, the turning rate declined in the rLV-GDNF group and was no longer different from the rLV-GFPtreated control animals at 12 and 19 weeks ( $\approx 1-3$ turns/min). Values give means \pm SEM. An asterisk indicates a significant difference from the rLV-GFP group.

between 2.6 and $4.2 \mathrm{ng} / \mathrm{mg}$ tissue (Fig. 1C). The levels of GDNF on the contralateral, nontransduced side in the rLV-GDNFinjected animals were $\sim 0.017 \mathrm{ng} / \mathrm{mg}$ tissue (effect of side, $\left.F_{(1,39)}=221.32 ; p<0.0001\right)$. In animals receiving the rLV-GFP vector, the endogenous GDNF tissue levels were $\sim 0.006 \mathrm{ng} / \mathrm{mg}$ tissue on the injected side and did not differ significantly from the contralateral nontransduced side (effect of side, $F_{(1,40)}=0.14$; $p=0.71)$.

\section{Continuous striatal GDNF overexpression enhances DA turnover and motor asymmetry in intact animals}

The time-dependent effects of striatal GDNF overexpression on DA, DOPAC, and HVA levels in the striatum were evaluated at 1 , 3 , and 6 weeks after rLV-GDNF injection into the striatum (Fig. 2). GDNF did not induce any significant changes in striatal DA (Fig. 2A) or DOPAC (Fig. $2 B$ ) levels at any time point. In contrast, the HVA levels (Fig. 2C) were significantly increased by $\sim 80 \%$ in the rLV-GDNF group at 1 week (effect of vector, $F_{(1,24)}=22.99 ; p<0.0001$ ), and the HVA/DA ratio (Fig. $2 D$ ) was significantly higher in the GDNF group at all time points (effect of vector, $\left.F_{(1,24)}=68.35 ; p<0.0001\right)$, reflecting an increased striatal DA turnover or release in the GDNF-treated animals. The increase in DA turnover was most pronounced at 1 week (twofold increase) and was progressively reduced by 3 and 6 weeks (effect of time point, $F_{(2,24)}=11.29 ; p<0.001$ ) but still remained significantly elevated above control levels. The increased HVA/DA ratio in the GDNF-treated animals may reflect an enhanced extraneuronal degradation of DA or DOPAC after release from the nerve terminals. This may also explain the lack of increase in DOPAC levels in these animals.

The rLV-GDNF-treated animals displayed a significant amphetamine-induced contralateral turning at the early time points after vector injection, ranging from 5.3 to 7.3 turns $/ \mathrm{min}$ (Fig. $2 E$ ), which was not observed in the rLV-GFP-injected control group (0.1-1.6 turns/min). This effect was maintained up to 6 weeks after injection but was no longer different from control at the longer (12 and 19 weeks) time points.

\section{Continuous striatal GDNF overexpression induces selective} downregulation of $\mathrm{TH}$ in the intact nigrostriatal DA system Immunohistochemical analysis of $\mathrm{TH}$ protein expression in the striatum was performed at $1,3,6$, and 12 weeks after rLV injection. Densitometry measurements of the striatal TH-positive innervation showed a significant, but delayed, decrease in the THpositive fiber staining on the injected side in the rLV-GDNF group, which was first detectable at 6 weeks $(-27 \%)$ after injection and further developed at 12 weeks $(-45 \%)$ (Fig. 3C). The reduction was most pronounced in the caudal part $(-36 \pm 4 \%$ at 6 weeks and $-61 \pm 7 \%$ at 12 weeks) (Fig. $3 B$ ) and less in the rostral and central parts $(-22 \pm 2 \%$ at 6 weeks and $-52 \pm 7 \%$ at 12 weeks) (Fig. 3A). This effect was not observed on the noninjected contralateral side (Fig. $3 A, B$ ). No significant change in TH-positive fiber staining was observed in the rLV-GFP-injected control animals at any time point (effect of vector, $F_{(1,36)}=45.89$; $p<0.0001$ ), indicating that the reduced TH immunoreactivity seen in the rLV-GDNF-injected animals was induced by GDNF and not the rLV vector per se. Staining for VMAT-2 immunoreactivity on adjacent sections showed that the expression of this protein, which is a good marker for the integrity of the DA axon terminals, was unaffected in the rLV-GDNF-injected striatum (Fig. 3D-F), suggesting that the GDNF-induced downregulation was selective for the TH protein.

The reductions in striatal TH protein expression were confirmed by Western blot analysis of $\mathrm{TH}$ in striatal tissue samples (Fig. $4 A$ ). In the GDNF-treated animals, TH protein levels were unaffected at 1 and 3 weeks but reduced to $36 \pm 3 \%$ of control side at 6 weeks. This low level was maintained at 12 and 24 weeks after injection (Fig. 4A). Consistent with the reduced levels of TH protein, there was a substantial reduction in striatal TH enzyme activity in the GDNF-treated animals, as measured by an in vitro assay on striatal tissue homogenates. This assay is performed under optimized conditions in the presence of the cofactor biopterin and is based on the release of tritiated $\mathrm{H}_{2} \mathrm{O}$ from L-[3,5${ }^{3} \mathrm{H}$ ]tyrosine during the hydroxylation reaction. This assay measures the activity of nonphosphorylated TH enzyme (because phosphate groups are easily lost during the homogenization of the tissue) and is correlated primarily to the amount of TH protein present in the tissue homogenates. The in vitro $\mathrm{TH}$ enzyme activity was significantly reduced in the GDNF-treated group starting at 3 weeks after the rLV injections $(-41 \pm 2 \%)$ (Fig. $4 B$ ) and was further reduced at 6 weeks $(-66 \pm 6 \%)$ and still maintained at this low level by 12 and 24 weeks after injection. This effect was not observed in the rLV-GFP-injected animals (effect of vector, $F_{(1,40)}=117.34 ; p<0.0001$ ), nor was there a significant difference between the contralateral nontransduced side in the GDNF-treated animals and the contralateral side in rLV-GFPinjected animals (effect of side, $F_{(1,40)}=0.06 ; p=0.81$ ).

Because the homogenization methods used in this study for determination of the $\mathrm{TH}$ protein levels in the striatal tissue (using the in vitro $\mathrm{TH}$ enzyme activity and Western blot analysis) were not compatible with procedures required for preservation of the 
A. $\mathrm{TH}$

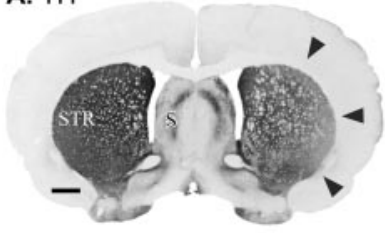

D. VMAT-2

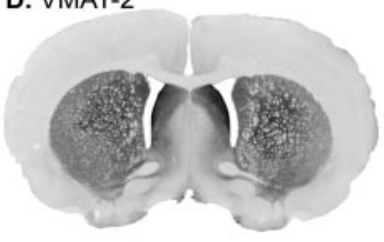

B. $\mathrm{TH}$

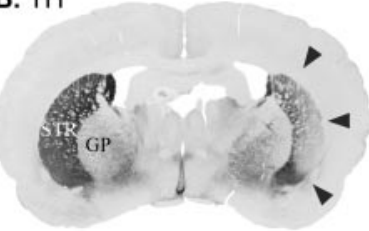

E. VMAT-2

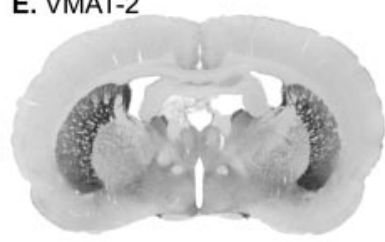

C

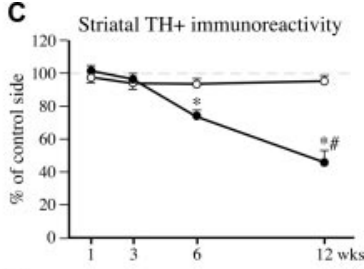

F

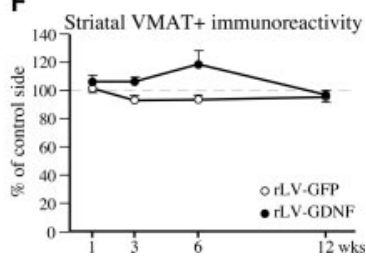

Figure 3. Effects of striatal rLV-GDNF delivery on TH and VMAT-2 immunoreactivity in the striatum. $A, B$, Photomicrographs of coronal sections through the rostral $(A)$ and caudal $(B)$ striatum, immunostained for TH at 6 weeks after rLV injection. Note the reduced TH immunoreactivity on the injected (right) side (arrowheads). C, Densitometry measurements of the striatal fiber staining at 1, 3, 6, and 12 weeks showed a significant decrease $(p<0.001)$ in TH-positive immunoreactivity on the injected side in the rLV-GDNF group at 6 and 12 weeks compared with the rLV-GFP-treated group. The reduction in TH-positive immunoreactivity was most pronounced in the caudal striatum $(B)$ and to a lesser extent in the rostral striatum $(A) . D, E$, Photomicrographs of adjacent coronal sections immunostained for VMAT-2 at 6 weeks after rLV injection. $F$, The VMAT-2-positive immunoreactivity was not significantly affected at any time point $(p>0.05)$. Values give means \pm SEM. An asterisk indicates a significant difference from the rLV-GFP-treated group; a number sign indicates a significant difference between 3 and 6 weeks in the rLV-GDNF group ( $p<0.0001$ ). Scale bar: (in $A) A, B, D, E, 1 \mathrm{~mm}$. S, Septum; GP, globus pallidus; STR, striatum.
A

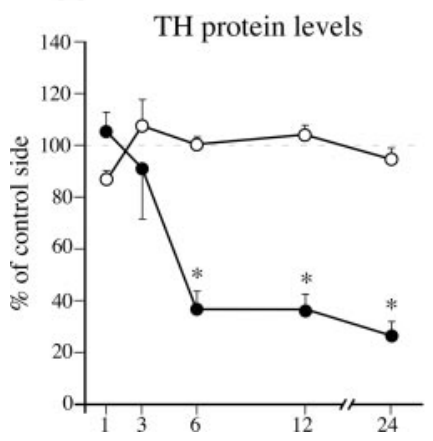

B

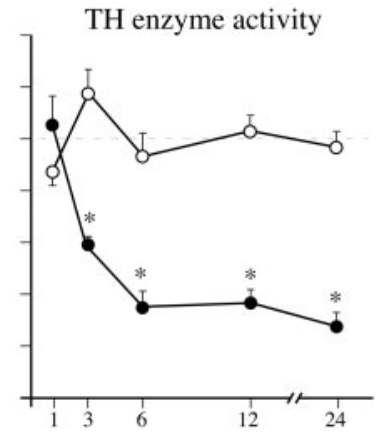

C

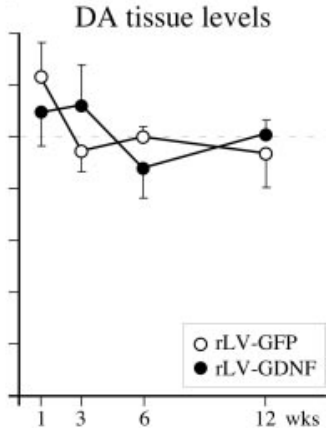

Figure 4. Biochemical analyses in striatal tissue samples at different time points after rLV-GDNF vector injection in the striatum $\left(1 \times 10^{5} \mathrm{TU}\right) . A$, TH protein levels were determined by Western blot analysis and showed significant reductions $(p<0.0001)$ at 6 weeks $(36.1 \pm 3.5 \%)$ in the rLV-GDNF group; these reductions were maintained at the later time points ( 12 and 24 weeks). $B$, Measurement of TH enzyme activity showed a significant decrease $(p<0.0001)$ at 3 weeks $(58.6 \pm 2.1 \%)$ in the rLV-GDNF group. The TH enzyme activity was further reduced at 6 weeks $(34.4 \pm 6.4 \%)$ and maintained at this low level at 12 and 24 weeks. $C$, Determination of DA levels did not reveal any significant changes between the groups at any time point $(p>0.05)$. Values give means \pm SEM. An asterisk indicates a significant difference from the rLV-GFP group.

phosphorylation state of the TH enzyme, we were unable to determine the effects of GDNF on this parameter. Instead, we estimated the activity of the TH enzyme in vivo by administering an inhibitor of the AADC enzyme (NSD-1015) 30 min before decapitation. The rate of accumulation of DOPA over the $30 \mathrm{~min}$ period provides an in vivo measure of the DOPA production rate, which in turn reflects the in vivo activity of the TH enzyme (including phophorylation status). At 6 weeks (i.e., at a time point when the in vitro TH enzyme activity was decreased by 66\%) (Fig. $4 B$ ), the in vivo DOPA production rate was maintained at normal levels in the rLV-GDNF-injected striatum $(97.1 \pm 15.7 \%$ of control side in the rLV-GDNF group and $87.6 \pm 9.0 \%$ of control side in the rLV-GFP group; $p>0.05)$. The steadystate striatal DA tissue levels (Fig. 4C) remained equal to the DA levels in the rLV-GFP group at all time points analyzed (effect of vector, $F_{(1,31)}=1.36 ; p=0.27$ ). No difference was observed between the contralateral nontransduced sidesin rLV-GFP- or rLVGDNF-injected animals at any time point (effect of side, $F_{(1,31)}=0.06 ; p=$ 0.81 ), and the DA tissue levels were thus expressed as a percentage of the contralateral side (Fig. 4C).

\section{Downregulation of $\mathrm{TH}$ expression in the intact nigrostriatal DA system is dependent on the level of striatal GDNF expression}

To evaluate whether the effects of GDNF on $\mathrm{TH}$ protein expression in the intact nigrostriatal DA system were dose dependent, different amounts of the rLV-GDNF vector (ranging between $4 \times 10^{3}$ and $1 \times$ $10^{5} \mathrm{TU}$ ) were injected in the striatum, and the animals were killed 6 weeks after rLV injection (i.e., at the time point when the GDNF-induced downregulation of $\mathrm{TH}$ is first observed) (Figs. 3C, $4 A)\left(1 \times 10^{5} \mathrm{TU}\right.$ injected). Striatal GDNF levels were $0.10 \pm 0.03 \mathrm{ng} / \mathrm{mg}$ tissue in the $4 \times 10^{3} \mathrm{TU}$ group and increased in a dose-dependent manner to $\sim 7.4 \pm 1.1 \mathrm{ng} / \mathrm{mg}$ tissue in the $1 \times 10^{5}$ TU group (effect of dose, $F_{(4,48)}=$ $18.45 ; p<0.0001$ ) (Fig. 5A). Baseline (i.e., endogenous) levels of GDNF were $\sim 0.011-0.018 \mathrm{ng} / \mathrm{mg}$ tissue in the contralateral striatum in the rLV-GDNFinjected animals and $\sim 0.002 \mathrm{ng} / \mathrm{mg}$ tissue in the rLV-GFP-injected striatum. In the rLV-GDNF-injected animals, detectable levels of GDNF were also observed in the ipsilateral SN and ranged from $0.06 \mathrm{ng} / \mathrm{mg}$ tissue in the lowest-dose group to $1.0 \mathrm{ng} / \mathrm{mg}$ tissue in the highest-dose group (Fig. 5A). The basal GDNF levels in the contralateral $\mathrm{SN}$ were $\sim 0.011 \mathrm{ng} / \mathrm{mg}$ tissue.

Striatal TH-positive fiber staining was significantly decreased by $27-31 \%$ in the rLV-GDNF groups receiving the higher doses of the rLV vector $\left(1 \times 10^{4}\right.$ to $1 \times 10^{5}$ TU) (Fig. 5B), whereas it was not significantly reduced in the low-dose rLV-GDNF group $\left(4 \times 10^{3} \mathrm{TU}\right)$. The magnitude of this effect was similar to the reductions seen in the time course study at 6 weeks after vector injection (compare Fig. 3C). Striatal VMAT-2 expression was unchanged at all dose levels (Fig. 5C).

Similar to the time course study, striatal TH enzyme activity (Fig. 5D) was reduced in all dose groups at 6 weeks after the vector injection, compared with the rLV-GFP control group. The reduction was significantly higher in the groups receiving the highest doses $\left(4 \times 10^{4}\right.$ to $\left.1 \times 10^{5} \mathrm{TU}\right)$ of the rLV-GDNF vector $(-72 \%)$, compared with the groups receiving the lowest doses $(-43 \%)$. In contrast, the in vivo DOPA production rate was not changed in the rLV-GDNF-treated animals (Fig. $5 E$ ), indicating that in vivo DA synthesis was not affected at any dose level. Consistent with this, the striatal tissue DA levels were maintained at a close to normal level in all rLVGDNF-treated groups (Fig. 5F). 
Nigral GDNF delivery induces downregulation of $\mathrm{TH}$ in the intact nigrostriatal DA system

To investigate the role of the site of GDNF delivery, we injected the rLV-GDNF vector at the highest dose $\left(1 \times 10^{5} \mathrm{TU}\right)$ into the $\mathrm{SN}$, and the animals were killed 6 weeks after injection. GDNF protein was widely distributed in the midbrain (Fig. $6 \mathrm{~A}$ ), and the GDNF levels in the SN, estimated by ELISA, were $\sim 2.4 \mathrm{ng} / \mathrm{mg}$ tissue on the transduced side (Fig. 6C). The endogenous GDNF levels were $\sim 0.06 \mathrm{ng} / \mathrm{mg}$ tissue in the contralateral $\mathrm{SN}$ and $\sim 0.01$ $\mathrm{ng} / \mathrm{mg}$ tissue in animals receiving $\mathrm{rLV}$ GFP into the SN. The GDNF levels in the ipsilateral striatum, $0.09 \mathrm{ng} / \mathrm{mg}$ tissue (Fig. $6 C$ ), were well above that on the contralateral noninjected side $(0.01 \mathrm{ng} / \mathrm{mg}$ tissue), suggesting some anterograde transport of GDNF to the striatum. However, the level of GDNF in the striatum was not detectable by immunohistochemistry (Fig. 6B). Double labeling of TH (Fig. 6G) and GFP (Fig. 6H) in midbrain sections from animals injected with the rLV-GFP control vector showed that nigral $\mathrm{TH}$-positive cells were rarely colabeled with GFP (Fig. 6I). This most likely reflects the poor efficiency of the cytomegalovirus promoter (used in the present rLV vector construct) to drive transgene expression in nigral DA neurons (Rosenblad et al., 2000b) rather than the ability of the rLV vector to transduce the DA neurons in the midbrain (Déglon et al., 2000).

Expression of GDNF in the SN induced reductions in the TH-positive fiber staining in the striatum $(-34 \%$ ) (Fig. $6 D$ ) that were similar to those seen in the animals in which GDNF was expressed in the striatum (compare Fig. 3C). This was accompanied by a significant decrease $(-45 \%)$ in the TH enzyme activity in the rLVGDNF-injected animals (Fig. 6E). No difference was observed between the contralateral sides in rLV-GFP- or rLV-GDNF-injected animals (effect of side, $F_{(1,8)}=0.85 ; p=$ $0.38)$. Striatal VMAT-2 expression remained at normal levels in the rLV-GDNF-treated animals (Fig. 6D).

\section{Discussion}

We used an rLV vector to study the effects of long-term continuous GDNF overexpression on intact nigrostriatal DA neurons in the rat. Intrastriatal or intranigral delivery of the vector resulted in high (2-4 ng of GDNF/mg tissue) and sustained levels of GDNF in the striatum and midbrain, respectively, for at least 6 months. Continuous overexpression of GDNF in the striatum and SN (from the intrastriatal route of delivery) or in $\mathrm{SN}$ only (from the intranigral delivery) induced a marked downregulation of the $\mathrm{TH}$ protein in the striatal DA terminals, whereas striatal VMAT-2 expression was unchanged. VMAT-2 is located preterminally on the DA storage vesi-

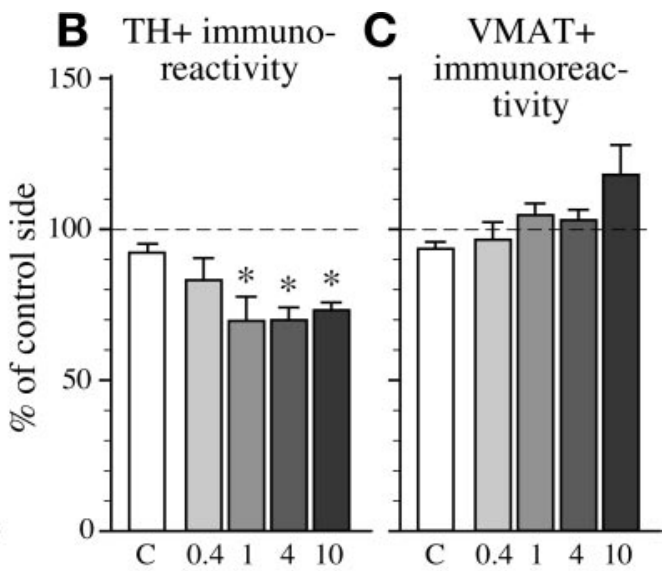

Number of transducing units $\left(\times 10^{4}\right)$

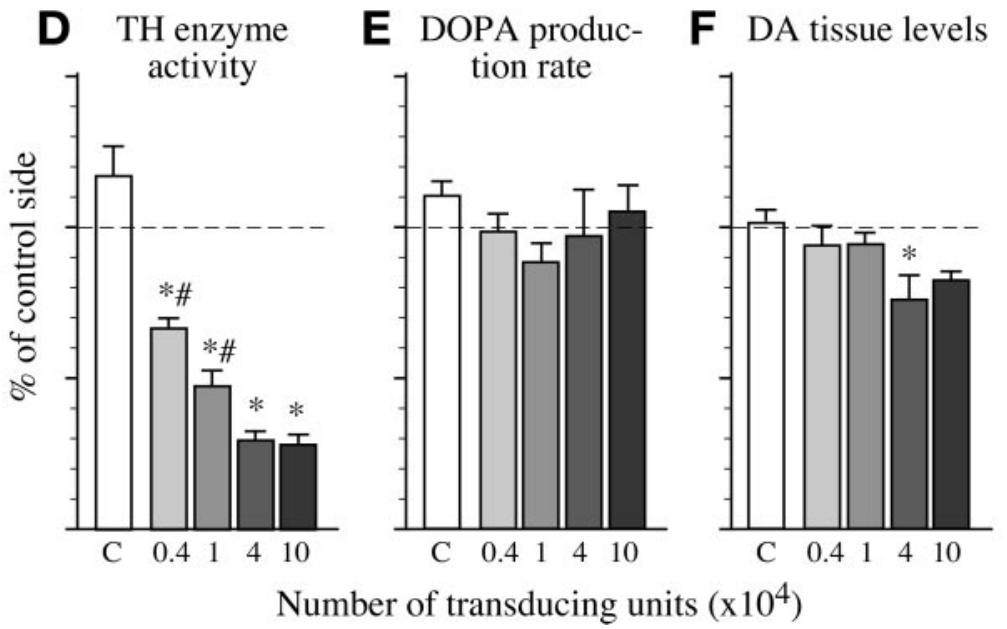

Figure 5. Histological and biochemical analyses at 6 weeks after injection of different doses of rLV-GDNF in the striatum $\left(0.4-10 \times 10^{4} \mathrm{TU}\right) . A$, GDNF tissue levels (nanograms per milligram of tissue) were determined by ELISA in striatum and SN. The GDNF levels in the striatum ranged from $0.10 \pm 0.03 \mathrm{ng} / \mathrm{mg}$ tissue in the $0.4 \times 10^{4} \mathrm{TU}$ group to $7.4 \pm 1.1 \mathrm{ng} / \mathrm{mg}$ tissue in the $10 \times 10^{4} \mathrm{TU}$ group. The GDNF levels detected in the SN were $0.06 \pm 0.01 \mathrm{ng} / \mathrm{mg}$ tissue in the lowest-dose group and increased to $1.01 \pm 0.14 \mathrm{ng} / \mathrm{mg}$ tissue in the highest-dose group. $B$, Densitometry measurements of striatal TH-positive immunoreactivity not changed in the group receiving the lowest dose $\left(0.4 \times 10^{4} \mathrm{TU}\right)$. C, Densitometry measurements of VMAT- 2 immunoreactivity in the striatum did not show any significant differences between groups $(p>0.05)$. D, TH enzyme activity measured in striatal tissue samples showed significant reductions $(p<0.0001)$ in all GDNF-treated groups compared with the rLV-GFP-treated control group. The magnitude of reduction was significantly higher in the rLV-GDNF groups receiving $4-10 \times 10^{4} \mathrm{TU}(-72 \pm$ $3 \%$ ) compared with the lower-dose groups $(-43 \pm 4 \%)$. E, Determination of the in vivo DOPA production rate did not show any significant changes $(p>0.05)$ in the rLV-GDNF groups. F, Determination of DA levels in the striatal tissue samples showed a significant reduction $(p<0.05)$ in the rLV-GDNF group receiving $4 \times 10^{4} \mathrm{TU}$, whereas the other groups maintained their DA levels at a close to normal level. Values give means \pm SEM. An asterisk indicates a significant difference from the rLV-GFP control group; a number sign indicates a significant difference from the other rLV-GDNF-treated groups. C, Control.

cles in striatum and has been shown to disappear progressively as the DA innervation is lost in PD patients (Miller et al., 1999). The absence of changes in VMAT-2 expression indicates that the nigrostriatal DA fiber innervation was normal in the GDNF-treated animals and that $\mathrm{TH}$ was selectively downregulated.

\section{GDNF-induced regulation of tyrosine hydroxylase}

In the present study, we observed a $60-70 \%$ reduction in $\mathrm{TH}$ protein expression after 6 weeks of continuous GDNF delivery, and these effects were persistent for up to 6 months. These observations most likely reflect effects of GDNF on long-term regulation of TH gene expression. In a parallel study, we observed significant reductions in TH mRNA expression $(-72 \%)$ in the SN 

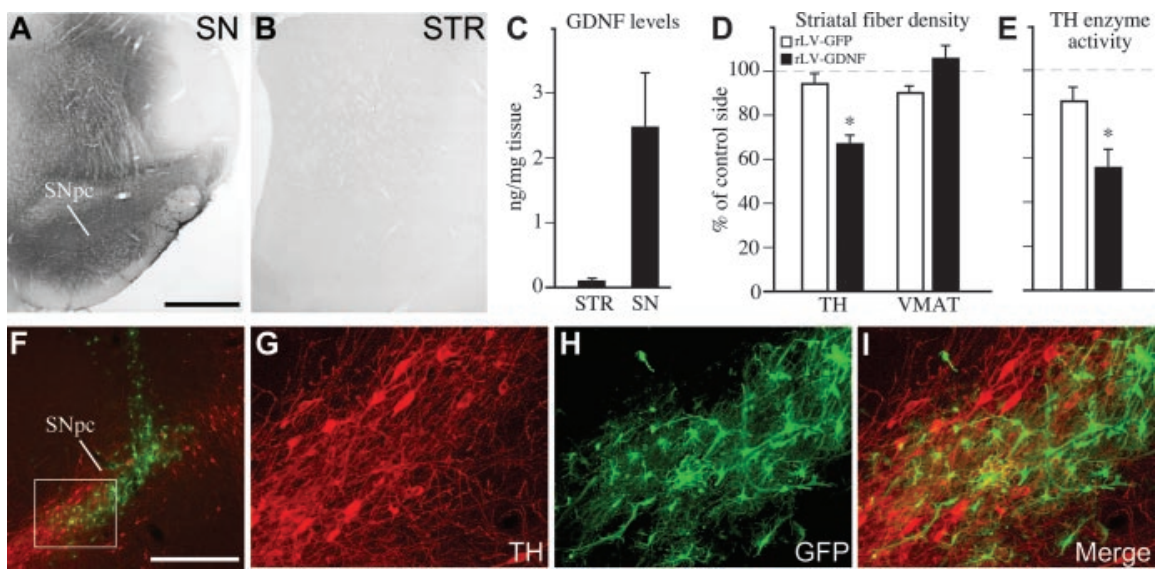

Figure 6. Histological and biochemical analyses at 6 weeks after injection of rLV-GDNF in the SN $\left(1 \times 10^{5}\right.$ TU). A, B, Photomicrographs of sections through the midbrain and striatum immunostained for GDNF showed that GDNF protein was widely spread in the midbrain on the injected side $(A)$, whereas no GDNF could be visualized in the ipsilateral striatum $(B)$. $C$, Determination of GDNF levels by ELISA in tissue samples from the striatum $(0.09 \pm 0.04 \mathrm{ng} / \mathrm{mg}$ tissue) and SN ( $2.4 \pm 0.8 \mathrm{ng} / \mathrm{mg}$ tissue) at 6 weeks after rLV injection. $D$, Densitometry measurements of the striatal fiber staining showed a significant decrease $(p<0.01)$ in TH-positive immunoreactivity on the injected side in the rLV-GDNF group ( $66.4 \pm 3.8 \%$ ), whereas VMAT-2 immunoreactivity was unchanged $(p>0.05)$. E, TH enzyme activity in the striatal tissue samples was significantly reduced $(p<0.05)$ in the rLV-GDNF group. F-I, Double labeling of TH (red) and GFP (green) in a section through the midbrain of an animal injected with rLV-GFP in the SN. TH-positive cells in the SN $(G)$ were rarely colabeled with GFP $(H)$ in the SN $(I)$. The box in $F$ depicts the approximate area from which the high-power pictures are taken. Scale bars: (in $A$ ) $A, B, 1 \mathrm{~mm} ; F, 500 \mu \mathrm{m}$; (in $F$ ) $G-I, 250 \mu \mathrm{m}$. Values give means \pm SEM. An asterisk indicates a significant difference from the rLV-GFP group. SNpc, Substantia nigra pars compacta.

bolus injections of GDNF, in doses of $1-100 \mu \mathrm{g}$, into either SN (Hudson et al., 1995; Hebert et al., 1996; Martin et al., 1996a; Hebert and Gerhardt, 1997), striatum (Martin et al., 1996a; Horger et al., 1998), or the lateral ventricle (Martin et al., 1996b; Lapchak et al., 1997b). These effects are usually associated with an enhancement in spontaneous and amphetamine-induced locomotor activity (Hudson et al., 1995; Martin et al., 1996a,b; Hebert and Gerhardt, 1997; Horger et al., 1998; Kobayashi et al., 1998; Kirik et al., 2000b) in the GDNFtreated animals. This is in line with the present study, in which the GDNF-treated animals initially (1-6 weeks) displayed an increased DA turnover and contralateral turning in response to amphetamine, indicating that DA neuron function was enhanced on the injected side.

Although we observed a downregulation of the TH protein after 6 weeks of continuous GDNF overexpression, results obtained after either single bolus injections of GDNF (Bowenkamp et al., 2000; Salvatore et al., 2003) or continuous protein infusions (Lapchak et al., 1997a; Lu

after 13 months of sustained GDNF overexpression in the striatum, suggesting that GDNF modulates TH gene expression (Rosenblad et al., 2003). The reductions in TH protein levels in the GDNF-treated animals were associated with similar reductions in TH enzyme activity $(-70 \%)$, as measured by an in vitro assay. However, the in vivo DOPA production rate was maintained at normal levels, indicating that the remaining $30 \%$ of the $\mathrm{TH}$ enzyme was in a more active state, possibly through increased phosphorylation, and was therefore able to maintain tissue DA concentrations at normal levels in the GDNF-treated animals. This concept is supported by the findings of Salvatore et al. (2003), who demonstrated that a single intrastriatal injection of $100 \mu \mathrm{g}$ of recombinant GDNF protein in aged rats resulted in a reduction in the $\mathrm{TH}$ protein levels by $40 \%$ at 4 weeks, whereas phosphorylation of the TH enzyme at Ser19, Ser31, and Ser41 was increased. Thus, the reductions in TH protein do not seem to be detrimental to the capacity of the DA neurons to maintain normal DA synthesis and content in the striatal terminals. This is further supported by the observation that the performance in different tests of spontaneous motor behavior (cylinder and staircase tests) is unaffected in the rLV-GDNF-treated animals (B. Georgievska and D. Kirik, unpublished data). Furthermore, in our previous study (Rosenblad et al., 2003), the GDNF-induced reductions in $\mathrm{TH}$ were not associated with any changes in the number of preterminal DA uptake sites and postsynaptic striatal D1 and D2 receptor binding in the striatum after 13 months of continuous GDNF expression, suggesting that the DA signaling is not affected in the GDNF-treated animals.

\section{Differential effects of GDNF in intact rodent and primates}

Acute delivery of GDNF to DA neurons in culture enhances neuronal excitability by modulation of ion channels (Yang et al., 2001; Wang et al., 2003) and increases the spontaneous firing rate and quantal size of terminal DA release (Pothos et al., 1998). In line with the observations in vitro, increases in DA levels and DA turnover have been demonstrated in intact rodents after single and Hagg, 1997) are inconsistent. Using immunohistochemical analysis, Bowenkamp et al. (2000) did not observe any changes in $\mathrm{TH}$ expression in the striatum or SN, whereas Lu and Hagg (1997) reported a significant reduction in TH immunostaining in the nigral DA neurons when a higher dilution of the TH primary antibody was used. Similarly, Salvatore et al. (2003) observed a significant reduction in striatal TH protein levels (as measured by Western blot analysis), whereas Lapchak et al. (1997) reported an increase in $\mathrm{TH}$ enzyme activity (as measured by the in vitro $\mathrm{TH}$ enzyme activity assay). The different results obtained in these studies could reflect the different methods used to analyze the TH expression.

The effects of GDNF on the intact nigrostriatal DA system in young and aged primates are more consistent. In aged monkeys, in which the nigral DA neurons remain intact but in a dysfunctional state, administration of GDNF to the nigrostriatal system, either by GDNF infusion (Grondin et al., 2003) or using an rLV vector (Kordower et al., 2000), has been shown to upregulate DA neuron function by increasing DA release, turnover, and storage in the caudate-putamen, accompanied by a restoration of $\mathrm{TH}$ expression in the nigral DA neurons. Similarly, we observed that rAAV-mediated overexpression of GDNF at high levels (9-18 $\mathrm{ng} / \mathrm{mg}$ tissue) in the caudate-putamen in young marmosets resulted in a substantial (twofold) increase, rather than decrease, in TH protein levels at 3 months after vector delivery (A. Eslamboli, Georgievska, R. Ridley, H. Baker, N. Muzyczka, C. Burger, R. Mandel, L. Annett, and Kirik, unpublished data). Thus, it appears that there are differential actions of GDNF on $\mathrm{TH}$ gene expression in primates versus rodents.

\section{A proposed model for the effects of GDNF on intact DA neurons}

Available experimental data show that exogenously administered GDNF may exert two different types of effects on intact DA neurons, either by (1) stimulating DA neuron function and transmitter release or (2) regulating the expression of the TH enzyme. 
These two effects could either be causally linked or occur as parallel events, independent of each other.

Based on the data obtained in vitro and in vivo, GDNF might mediate its effects on intact DA neurons, at least in part either by increasing the excitability of the neurons and thereby the release of DA from the nigrostriatal terminals or by increasing the $\mathrm{TH}$ enzyme activity (e.g., by increased phosphorylation) (Salvatore et al., 2003) so that more DA is synthesized and stored in the vesicles. In parallel to, or as a consequence of, the stimulatory effects on DA transmission, long-term continuous GDNF stimulation also induces a downregulation of $\mathrm{TH}$ in intact DA neurons, at least in rodents. DA neurons have several compensatory mechanisms for adjusting the activity of the DA transmitter machinery in response to changes in functional activity. This may occur both at the level of TH phosphorylation and on $\mathrm{TH}$ gene expression. Thus, a GDNF-induced increase in DA release from the DA terminals (as indicated by increased DA turnover and amphetamineinduced rotation) may lead to overactivation of presynaptic DA autoreceptors and a reduction of TH protein phosphorylation (Salah et al., 1989) and hence TH enzyme activity. TH activity may be further reduced by a direct feedback action of DA on the function of the $\mathrm{TH}$ enzyme (Kumer and Vrana, 1996). The present results suggest an additional mechanism, where binding of GDNF to the GFR $\alpha 1$-RET receptor complex in the rodent might activate cellular signaling involved in regulation of $\mathrm{TH}$ gene expression. We propose that DA neurons under continuous GDNF stimulation are able to compensate for increased DA synthesis and release by decreasing TH enzyme activity and that this may be mediated by a combination of the shortterm regulatory machinery (direct feedback inhibition and overstimulation of presynaptic DA autoreceptors) and a long-term downregulation of $\mathrm{TH}$ gene expression, which is slower in onset. This model is supported by the fact that it takes $\sim 3-6$ weeks for the $\mathrm{TH}$ downregulation to develop and that the DA turnover and amphetamine-induced rotation at this time point start to decline and the motor asymmetry is completely lost by 19 weeks after vector delivery. This compensatory mechanism would serve to maintain long-term DA neuron function within the normal range.

\section{Conclusion}

The GDNF-induced downregulation of TH did not cause any functional impairment in the intact nigrostriatal DA system. In our previous study (Georgievska et al., 2002a), we observed a similar downregulation of $\mathrm{TH}$ in 6-OHDA-lesioned rats after GDNF gene delivery to the striatum. These animals failed to show functional recovery, despite a near-complete protection of the nigrostriatal DA pathway. This raises the possibility that longterm downregulation of $\mathrm{TH}$ may affect functional recovery in lesioned animals, in which the DA system is in a compromised state. Importantly, however, in these animals, we also observed an extensive GDNF-induced aberrant sprouting of TH-positive fibers in globus pallidus, entopeduncular nucleus, and SN. Therefore, in future studies, it will be important to investigate the relative contributions of $\mathrm{TH}$ downregulation and aberrant sprouting to functional recovery in lesioned animals.

\section{References}

Beck KD, Valverde J, Alexi T, Poulsen K, Moffat B, Vandlen RA, Rosenthal A, Hefti F (1995) Mesencephalic dopaminergic neurons protected by GDNF from axotomy-induced degeneration in the adult brain. Nature 373:339-341.

Bilang-Bleuel A, Revah F, Colin P, Locquet I, Robert JJ, Mallet J, Horellou P (1997) Intrastriatal injection of an adenoviral vector expressing glialcell-line-derived neurotrophic factor prevents dopaminergic neuron de- generation and behavioral impairment in a rat model of Parkinson disease. Proc Natl Acad Sci USA 94:8818-8823.

Björklund A, Rosenblad C, Winkler C, Kirik D (1997) Studies on neuroprotective and regenerative effects of GDNF in a partial lesion model of Parkinson's disease. Neurobiol Dis 4:186-200.

Björklund A, Kirik D, Rosenblad C, Georgievska B, Lundberg C, Mandel RJ (2000) Towards a neuroprotective gene therapy for Parkinson's disease: use of adenovirus, AAV and lentivirus vectors for gene transfer of GDNF to the nigrostriatal system in the rat Parkinson model. Brain Res 886:82-98.

Bowenkamp KE, Ujhelyi L, Cline EJ, Bickford PC (2000) Effects of intrastriatal GDNF on motor coordination and striatal electrophysiology in aged F344 rats. Neurobiol Aging 21:117-124.

Choi-Lundberg DL, Lin Q, Chang YN, Chiang YL, Hay CM, Mohajeri H, Davidson BL, Bohn MC (1997) Dopaminergic neurons protected from degeneration by GDNF gene therapy. Science 275:838-841.

Déglon N, Tseng JL, Bensadoun JC, Zurn AD, Arsenijevic Y, Pereira de Almeida L, Zufferey R, Trono D, Aebischer P (2000) Self-inactivating lentiviral vectors with enhanced transgene expression as potential gene transfer system in Parkinson's disease. Hum Gene Ther 11:179-190.

Gash DM, Zhang Z, Gerhardt G (1998) Neuroprotective and neurorestorative properties of GDNF. Ann Neurol 44:S121-125.

Georgievska B, Kirik D, Björklund A (2002a) Aberrant sprouting and downregulation of tyrosine hydroxylase in lesioned nigrostriatal dopamine neurons induced by long-lasting overexpression of glial cell line derived neurotrophic factor in the striatum by lentiviral gene transfer. Exp Neurol 177:461-474.

Georgievska B, Kirik D, Rosenblad C, Lundberg C, Björklund A (2002b) Neuroprotection in the rat Parkinson model by intrastriatal GDNF gene transfer using a lentiviral vector. NeuroReport 13:75-82.

Gill SS, Patel NK, Hotton GR, O'Sullivan K, McCarter R, Bunnage M, Brooks DJ, Svendsen CN, Heywood P (2003) Direct brain infusion of glial cell line-derived neurotrophic factor in Parkinson disease. Nat Med 9:589-595.

Grondin R, Cass WA, Zhang Z, Stanford JA, Gash DM, Gerhardt GA (2003) Glial cell line-derived neurotrophic factor increases stimulus-evoked dopamine release and motor speed in aged rhesus monkeys. J Neurosci 23:1974-1980.

Hebert MA, Gerhardt GA (1997) Behavioral and neurochemical effects of intranigral administration of glial cell line-derived neurotrophic factor on aged Fischer 344 rats. J Pharmacol Exp Ther 282:760-768.

Hebert MA, Van Horne CG, Hoffer BJ, Gerhardt GA (1996) Functional effects of GDNF in normal rat striatum: presynaptic studies using in vivo electrochemistry and microdialysis. J Pharmacol Exp Ther 279:1181-1190.

Horger BA, Nishimura MC, Armanini MP, Wang LC, Poulsen KT, Rosenblad C, Kirik D, Moffat B, Simmons L, Johnson Jr E, Milbrandt J, Rosenthal A, Björklund A, Vandlen RA, Hynes MA, Phillips HS (1998) Neurturin exerts potent actions on survival and function of midbrain dopaminergic neurons. J Neurosci 18:4929-4937.

Hudson J, Granholm AC, Gerhardt GA, Henry MA, Hoffman A, Biddle P, Leela NS, Mackerlova L, Lile JD, Collins F, Hoffer BJ (1995) Glial cell line-derived neurotrophic factor augments midbrain dopaminergic circuits in vivo. Brain Res Bull 36:425-432.

Kearns CM, Cass WA, Smoot K, Kryscio R, Gash DM (1997) GDNF protection against 6-OHDA: time dependence and requirement for protein synthesis. J Neurosci 17:7111-7118.

Kirik D, Rosenblad C, Björklund A (2000a) Preservation of a functional nigrostriatal dopamine pathway by GDNF in the intrastriatal 6-OHDA lesion model depends on the site of administration of the trophic factor. Eur J Neurosci 12:3871-3882.

Kirik D, Rosenblad C, Björklund A, Mandel RJ (2000b) Long-term rAAVmediated gene transfer of GDNF in the rat Parkinson's model: intrastriatal but not intranigral transduction promotes functional regeneration in the lesioned nigrostriatal system. J Neurosci 20:4686-4700.

Kobayashi S, Ogren SO, Hoffer BJ, Olson L (1998) Dopamine D1 and D2 receptor-mediated acute and long-lasting behavioral effects of glial cell line-derived neurotrophic factor administered into the striatum. Exp Neurol 154:302-314.

Kordower JH, Emborg ME, Bloch J, Ma SY, Chu Y, Leventhal L, McBride J, Chen EY, Palfi S, Roitberg BZ, Brown WD, Holden JE, Pyzalski R, Taylor MD, Carvey P, Ling Z, Trono D, Hantraye P, Déglon N, Aebischer P 
(2000) Neurodegeneration prevented by lentiviral vector delivery of GDNF in primate models of Parkinson's disease. Science 290:767-773.

Kumer SC, Vrana KE (1996) Intricate regulation of tyrosine hydroxylase activity and gene expression. J Neurochem 67:443-462.

Lapchak PA, Miller PJ, Jiao S (1997a) Glial cell line-derived neurotrophic factor induces the dopaminergic and cholinergic phenotype and increases locomotor activity in aged Fischer 344 rats. Neuroscience 77:745-752.

Lapchak PA, Jiao S, Collins F, Miller PJ (1997b) Glial cell line-derived neurotrophic factor: distribution and pharmacology in the rat following a bolus intraventricular injection. Brain Res 747:92-102.

Lotharius J, Barg S, Wiekop P, Lundberg C, Raymon HK, Brundin P (2002) Effect of mutant alpha-synuclein on dopamine homeostasis in a new human mesencephalic cell line. J Biol Chem 277:38884-38894.

Lu X, Hagg T (1997) Glial cell line-derived neurotrophic factor prevents death, but not reductions in tyrosine hydroxylase, of injured nigrostriatal neurons in adult rats. J Comp Neurol 388:484-494.

Mandel RJ, Spratt SK, Snyder RO, Leff SE (1997) Midbrain injection of recombinant adeno-associated virus encoding rat glial cell linederived neurotrophic factor protects nigral neurons in a progressive 6-hydroxydopamine-induced degeneration model of Parkinson's disease in rats. Proc Natl Acad Sci USA 94:14083-14088.

Martin D, Miller G, Cullen T, Fischer N, Dix D, Russell D (1996a) Intranigral or intrastriatal injections of GDNF: effects on monoamine levels and behavior in rats. Eur J Pharmacol 317:247-256.

Martin D, Miller G, Fischer N, Diz D, Cullen T, Russell D (1996b) Glial cell line-derived neurotrophic factor: the lateral cerebral ventricle as a site of administration for stimulation of the substantia nigra dopamine system in rats. Eur J Neurosci 8:1249-1255.

Miller GW, Erickson JD, Perez JT, Penland SN, Mash DC, Rye DB, Levey AI (1999) Immunochemical analysis of vesicular monoamine transporter (VMAT2) protein in Parkinson's disease. Exp Neurol 156:138-148.

Paxinos G, Watson C (1998) The rat brain in stereotaxic coordinates, Ed 4. San Diego: Academic.

Pothos EN, Davila V, Sulzer D (1998) Presynaptic recording of quanta from midbrain dopamine neurons and modulation of the quantal size. J Neurosci 18:4106-4118.

Reinhard Jr JF, Smith GK, Nichol CA (1986) A rapid and sensitive assay for tyrosine-3-monooxygenase based upon the release of $3 \mathrm{H} 2 \mathrm{O}$ and adsorption of $\left[{ }^{3} \mathrm{H}\right]$-tyrosine by charcoal. Life Sci 39:2185-2189.
Rosenblad C, Kirik D, Björklund A (2000a) Sequential administration of GDNF into the substantia nigra and striatum promotes dopamine neuron survival and axonal sprouting but not striatal reinnervation or functional recovery in the partial 6-OHDA lesion model. Exp Neurol 161:503-516.

Rosenblad C, Grønborg M, Hansen C, Blom N, Meyer M, Johansen J, Dagø L, Kirik D, Patel UA, Lundberg C, Trono D, Björklund A, Johansen TE (2000b) In vivo protection of nigral dopamine neurons by lentiviral gene transfer of the novel GDNF-family member neublastin/artemin. Mol Cell Neurosci 15:199-214.

Rosenblad C, Georgievska B, Kirik D (2003) Long-term striatal overexpression of GDNF selectively downregulates tyrosine hydroxylase in the intact nigrostriatal dopamine system. Eur J Neurosci 17:260-270.

Salah RS, Kuhn DM, Galloway MP (1989) Dopamine autoreceptors modulate the phosphorylation of tyrosine hydroxylase in rat striatal slices. J Neurochem 52:1517-1522.

Salvatore MF, Zhang J, Wilson PE, Large DM, Haycock JW, Bing G, Gash DM, Gerhardt GA (2003) Nigrostriatal neuron protein expression and phosphorylation following GDNF treatment of aged rats. Soc Neurosci Abstr 29:302.10.

Sauer H, Rosenblad C, Björklund A (1995) Glial cell line-derived neurotrophic factor but not transforming growth factor beta 3 prevents delayed degeneration of nigral dopaminergic neurons following striatal 6-hydroxydopamine lesion. Proc Natl Acad Sci USA 92:8935-8939.

Schmidt RH, Ingvar M, Lindvall O, Stenevi U, Björklund A (1982) Functional activity of substantia nigra grafts reinnervating the striatum: neurotransmitter metabolism and $\left[{ }^{14} \mathrm{C}\right] 2$-deoxy-D-glucose autoradiography. J Neurochem 38:737-748.

Tomac A, Lindqvist E, Lin LF, Ogren SO, Young D, Hoffer BJ, Olson L (1995) Protection and repair of the nigrostriatal dopaminergic system by GDNF in vivo. Nature 373:335-339.

von Schwedler U, Song J, Aiken C, Trono D (1993) Vif is crucial for human immunodeficiency virus type 1 proviral DNA synthesis in infected cells. J Virol 67:4945-4955.

Wang J, Chen G, Lu B, Wu CP (2003) GDNF acutely potentiates Ca2+ channels and excitatory synaptic transmission in midbrain dopaminergic neurons. NeuroSignals 12:78-88.

Yang F, Feng L, Zheng F, Johnson SW, Du J, Shen L, Wu CP, Lu B (2001) GDNF acutely modulates excitability and A-type $\mathrm{K}(+)$ channels in midbrain dopaminergic neurons. Nat Neurosci 4:1071-1078. 